特集 超臨場感技術

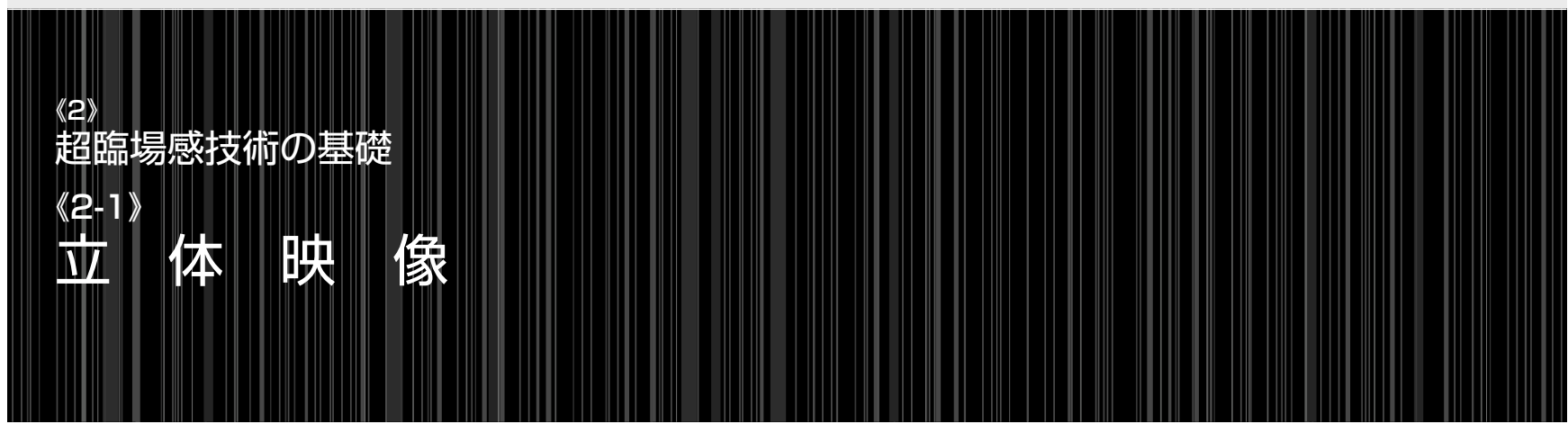

[正会員]高 木 康 博十

キーワード 立体表示, 立体ディスプレイ, 超臨場感, ホログラフィー, 超多眼

1 ま え がき

将来の超臨場感技術において，立体映像が果たす役割は 大きい. 超臨場感技術が何かは, 本特集1章「超臨場感技術 の概要」ですでに説明があったと思うが，そこでは現在実 用化されている技術を超えた究極の立体表示技術が用いら れるであろう。本稿では，このような将来の立体表示技術 を中心に紹介する。

超臨場感技術に用いられる立体表示に必要と考えられる 要件としては,

（1）裸眼表示

（2）安全性 (視覚疲労などの人体への悪影響がない)

(3) 高精細

(4) 多人数

(5) 大画面

が挙げられる．デバイス技術の限界から，現状ですべてを 満たす立体表示技術は存在しない。本稿では，デバイス開 発の課題も含めて, 将来の立体表示技術について説明する.

2 ホログラフィ

ホログラフィ1)は，物体からの波面を再生するため，現 在考えられている立体表示方式のなかで最も理想的な立体 表示方式と言われている.

電子的なホログラフィ表示の原理を図1に示す. 電子ホ ログラフィで用いられる表示デバイスは, 空間光変調器と 呼ばれる. 表示物体を物体点の集まりと考え, 空間光変調 器で物体点に集光する球面波を発生することで, 立体表示 を実現する. 空間光変調器としては, 2次元表示用の液晶 ディスプレイ等と同様に2次元的に並んだピクセル群を持 つものが一般的である.

上述のように，ホログラフィは空間に集光する光で物体 点を発生するため, 人間は物体点に対して目のピント合わ せできる，すなわち，図2 (a)に示すように，立体像に対し

†東京農工大学 大学院工学研究院

"Basics of Ultra-Realistic Communication Technologies; ThreeDimensional Image" by Yasuhiro Takaki (Institute of Engineering, Tokyo University of Agriculture and Technology, Tokyo)

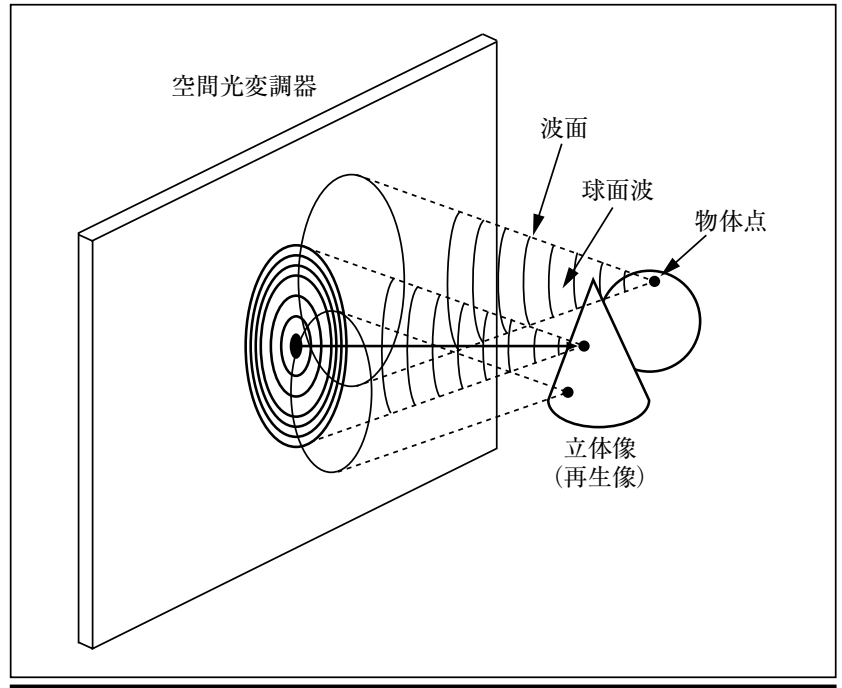

図 1 電子的ホログラフィによる立体表示

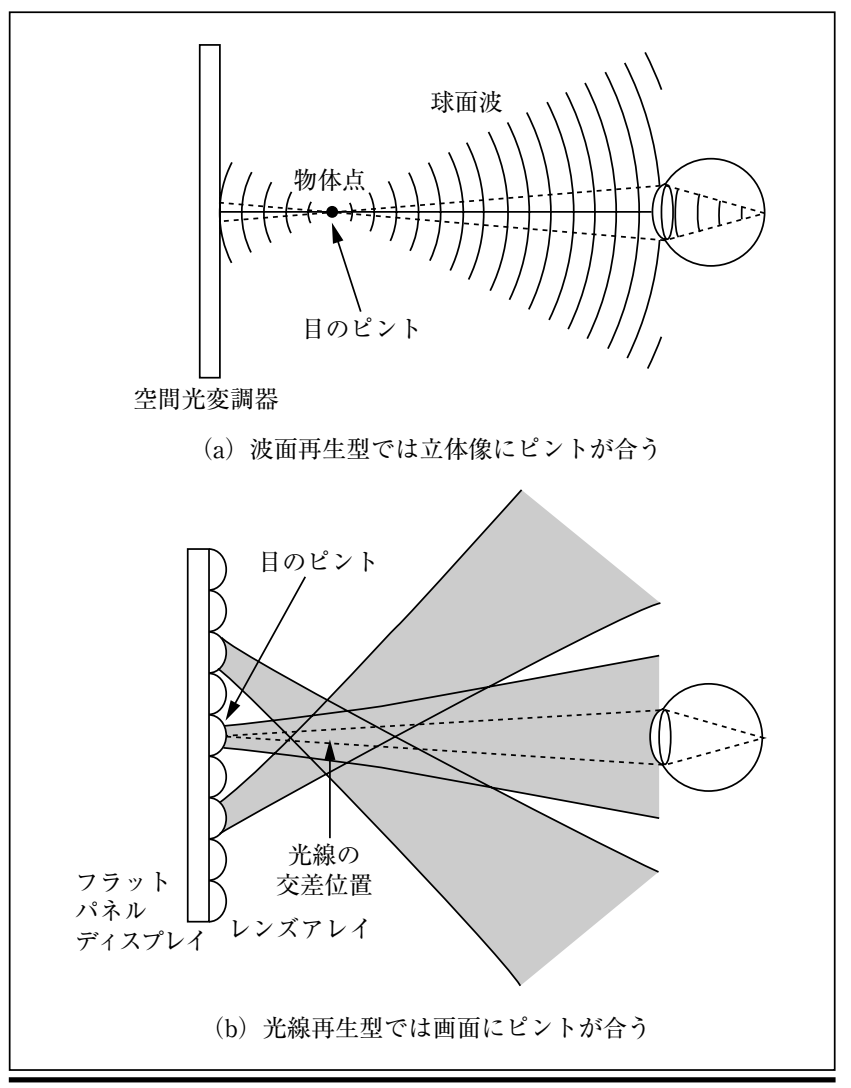

図2 波面再生型と光線再生型での目の調節 
て目のピントが合う。これに対して, 現在の立体表示方式 では, 図2（b）に示すように, スクリーンから広がる光線 で立体像を表示する. 光線の広がりは, 光線の表示角度ピ ッチと同程度にしないと立体像にモアレが生じる. そのた め, 目のピントは立体像ではなくスクリーン付近に合い, 「調節輻輳矛盾」という問題が生じる，調節とは，目のピン ト合わせ機能を言い，輻輳とは，両眼の回転角を基に三角 測量の原理で奥行きを知覚する機能を言う. 光線で立体表 示する場合は, 輻輳は正しく機能するが, 調節は正しく機 能しない.この二つの立体知覚の生理的要因の不一致が, 立体映像観察時の視覚疲労を引き起こすと言われている. ホログラム表示では, 調節が正しく機能するため, このよ うな問題は生じない.

電子的なホログラフィ表示の問題点は, 多人数と大画面 を実現するのが難しい点にある. 光の波面を再現するには, 波面の間隔が光の波長であるから, 図3に示すように, 空 間光変調器のピクセルピッチを光の波長程度にする必要が ある. サンプリング定理からピクセルピッチで再現できる 球面波の広がり角が決まり, 球面波の広がり角で立体像が 見える視域角が決まる. ピクセルピッチを $p$ で, 光の波長 を $\lambda$ で表すと, 視域角は $2 \sin ^{-1}(\lambda / 2 p)$ で与えられる。可 視光の波長は $0.4 \sim 0.8 \mu \mathrm{m}$ であるから, 実用的な視域を得る ためには，1 $\mu \mathrm{m}$ 以下のピクセルピッチが必要になる．また， ホログラム表示では, 2次元ディスプレイのように画面サ イズに比例してピクセルピッチを拡大することができない ため, 実用的な画面サイズを得るには, 莫大なピクセル数 が必要になる.

電子ホログラフィの実現では, 視域の拡大と画面サイズ の拡大が最大の課題である. その解決法が世界中で研究さ れている. 音響光学素子を用いる方法 ${ }^{2}$, 複数の空間光変 調器を用いる方法 ${ }^{3) \sim 5)}$, 時分割表示を用いる方法6), アイ トラッキングを用いる方法 ${ }^{8)}$, 解像度変換技術を用いる方

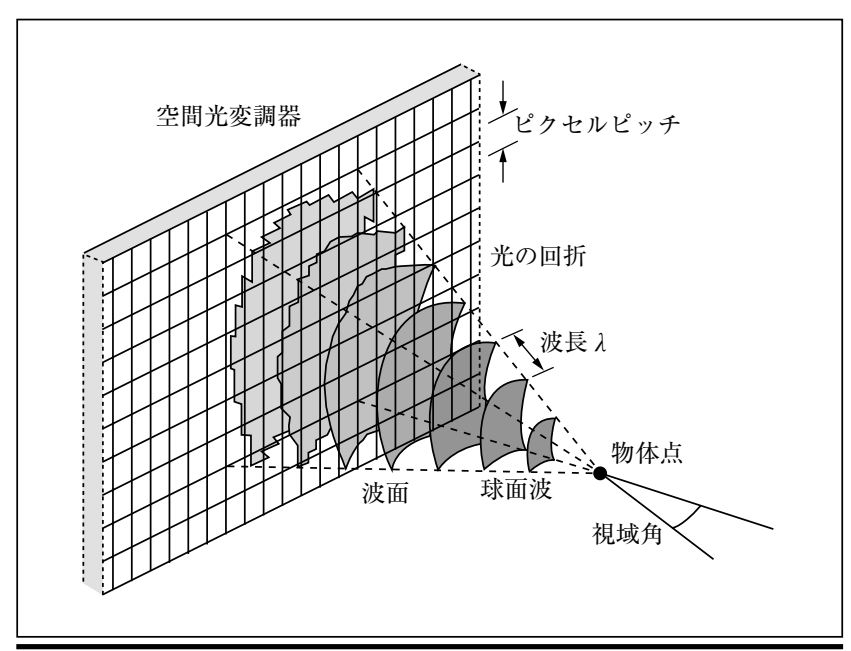

図3＼cjkstart電子ホログラフィーにおける空間光変調器のピクセルピッチと 視域角の関係
法 $^{8)}$, 水平走査を用いる方法 ${ }^{9)}$, 光書达み材料を用いる方法 10) などが提案されている.

また，電子ホログラフィには，スペックルによる画質劣 化や膨大な情報量などの課題もある.

\section{3 波面再生と光線再生}

裸眼立体表示は, 波面再生型と光線再生型に分類できる. 前者はすでに述べたホログラフィである. 後者は多眼表示 11) やインテグラルイメージング12) と呼ばれるもので，それ ぞれ，1次元レンズアレイ（レンチキュラレンズ）や2次元レ ンズアレイ (フライアイレンズ) を用いて, 光線の進行方向 を制御する ${ }^{13)}$.

波面再生型と光線再生型の違いについて説明する．波面 再生型は，すでに述べたように空間に集光点を発生するた め, 立体像に目のピントが合う。光線再生型では, 各光線 は，レンズアレイのあるスクリーン面でビーム径が最小に なり，スクリーンから離れると光線は広がる. 光線のビー ム径が最小になる面をスクリーンから離れた距離に設定す ることもできるが，その前後では光線は広がる. 光線再生 型ではインコヒーレントな光を用いるため, 広がった光線 を空間の一点で多数交差させても, ビーム径が小さくなる ことはない.したがって，ホログラム表示のように，空間 の任意の距離にビーム径が最小になる集光点を作り出すこ とはできない. そのため, 後述する超多眼表示を除いては, 光線再生型では調節輻輳矛盾が生じる.

また，波面再生型における集光点のビーム径は，理論的 には, 空間光変調器のピクセルピッチ程度にできる.すな わち，ミクロンオーダで物体の細部が表現できるため，高 精細な立体像が得られる。これに対して, 光線再生型では, 目のピントはスクリーン前後にあるため, 立体像の細部を 観察しようとすると，レンズアレイのレンズ構造が見える. 図4 (a) は光学的ホログラフィ，すなわち，写真技術で作製

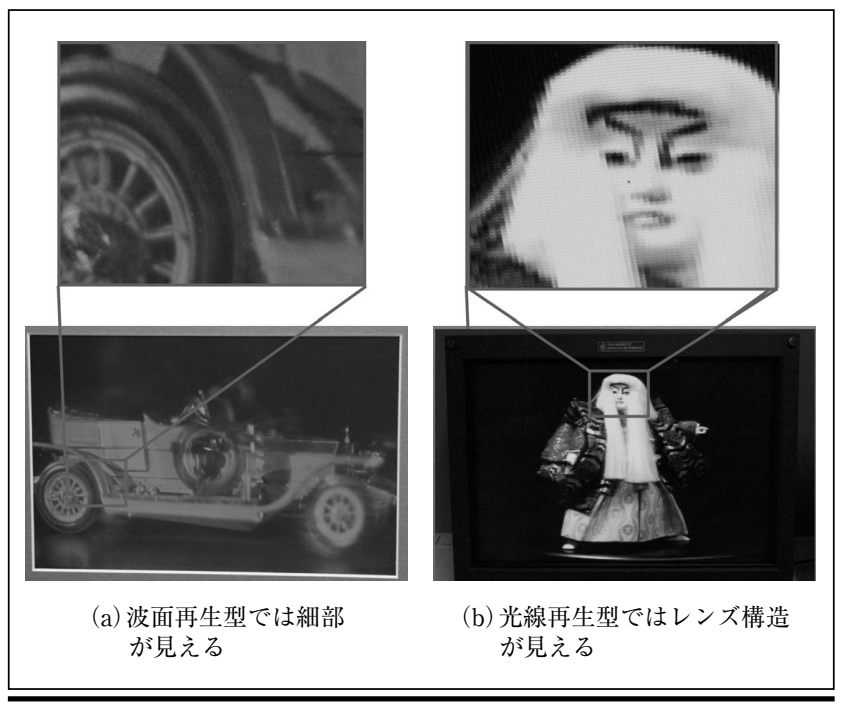

図4 波面再生型と光線再生型の再生像の違い（口絵力ラ一参照） 


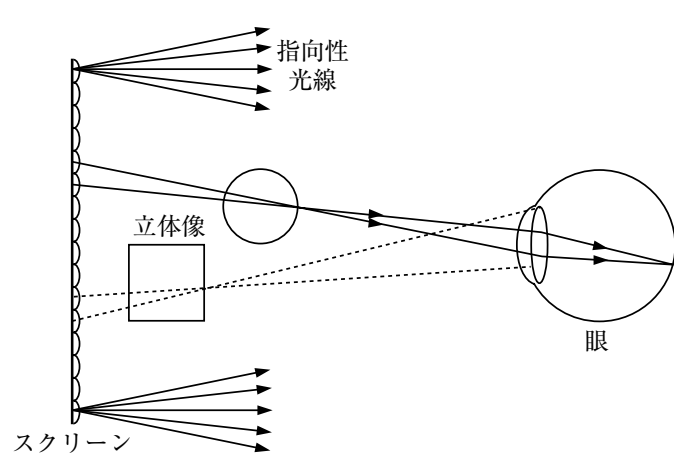

（a）高密度指向性表示

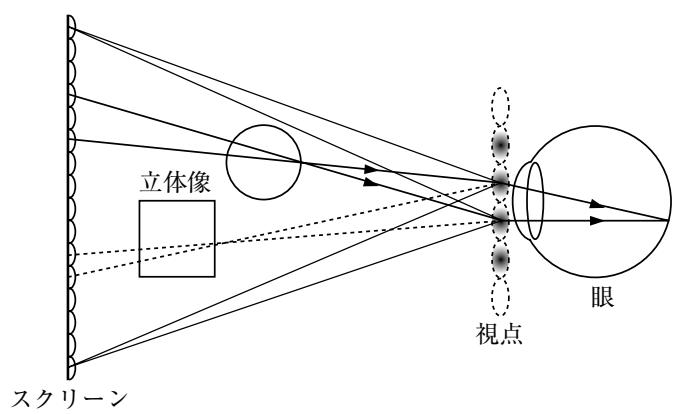

（b）超多眼表示

図5 光線再生型での調節応答の誘起

したホログラムの再生像を示す. 図4 (b) は, レンチキュラ レンズを用いた多眼式立体ディスプレイの再生像を示す.

光線再生型の優れている点は, 波面再生型に比べて, 視 域と画面サイズを大きくできる点にある. 光の偏向に, 微 細ピクセル構造による光の回折ではなく, レンズによる光 の屈折を用いるため, レンズ背面のピクセルの間隔を波長 オーダまで小さくする必要はない.なお, 光線再生型では, レンズアレイと組合せる表示デバイスとして液晶パネル等 のフラットパネルディスプレイが用いられる. 光線再生型 でも広い視域を得ることはそれほど容易ではないが，大き な画面サイズは単純に大型のフラットパネルディスプレイ を用いればよいので実現は容易である。そのため, 現状の 裸眼立体ディスプレイには光線再生型が用いられている.

\section{4 超多眼表示}

光線再生型で, 立体像への目のピント合わせを可能にす るのが超多眼表示 ${ }^{14)}$, あるいは, 高密度指向性表示 ${ }^{15)}$ であ る。これらは，小さな角度ピッチで光線を高密度に発生す ることで, 図5 (a) に示すように, 立体像の1点を通る光線 が2本以上同時に目の曈に入る状態を作り出す. 目のピン トをスクリーンに合わせると 2 点以上に分離して見え, 立 体像にピントを合わせると1点に見える. 輻輳と調節が一 致すると1点に見え, 調節輻輳矛盾が解決される.

ただし，光線のビーム径はスクリーン上で最小であるか ら，スクリーンに目のピントを合わせると複数のシャープ な点が見える，ここで，人間がボケを感じない奥行き範囲 は目の被写界深度で与えられ, 通常は瞳の大きさでその範 囲が決まる。曈に2本以上の光線が同時に入る状態では, 光線の広がりが実質的な曈となるため, 被写界深度は光線 の角度ピッチで決まり，その奥行き範囲が拡大する。この 拡大された被写界深度内では, 光線のボケは知覚されない ため, 安定的に立体像に対するピント合わせが可能になる ことが示されている16).

高密度指向性表示は, 上述のように, 光線の進行方向を
微小な角度ピッチでサンプリングする。これに対して，超 多眼表示は, 図5 (b) に示すように, 多眼表示の視点数を 増やし視点間隔を小さくすることで光線密度を高める．多 眼表示では, 空間に複数の視点を設定し, レンズアレイの 各レンズから各視点に集まる光線群でその視点から立体物 を見た視差画像を表示することで，裸眼立体表示を実現す る。通常の多眼表示では, 視点間隔を両眼間隔, あるいは, その半分程度に設定する。

光線の角度ピッチを小さくし高密度に光線を発生するた めには，スクリーンを構成する各レンズに多くのピクセル を対応させる必要がある, そのため, 高解像度なフラット パネルデイスプレイが必要になるが, 光の偏向にレンズを 用いるため, 必要な解像度はホログラムよりは低い。

超多眼表示や高密度指向性表示の難しさは, 従来の多眼表 示の10倍程度の画像情報を表示する必要がある点にある。そ のため, さまざまな表示システムが提案されている，光源 アレイの空間走查 ${ }^{14)}$, マルチプロジェクション方式15) 17) 18), 高精細液晶パネルを用いたレンチキュラ方式 $\left.{ }^{19)} 20\right)$, ヘッド マウント型 ${ }^{21)}$ などが提案されている。また，時分割表示の 利用22)，レンチキュラ方式とマルチプロジェクション方式の ハイブリッドな構成方法23)，フラットパネルディスプレイに 必要な解像度を低下させる方法 ${ }^{24)}$ などが研究されている.

超多眼表示や高密度指向性表示では, 小さな角度ピッチ で光線をサンプリングするため, 滑らかな運動視差が得ら れる. また, 微妙な光線変化が再現されるので, 光沢感や 透明感といった物質のもつ質感再現20)も可能になる.

\section{5 大画面表示}

スクリーンの大型化は, 臨場感の向上に大きな効果をも つ. そのため, 大画面かつ多人数で観察できる裸眼立体表 示システムが開発されている.

このような表示システムの実現には, 現状ではプロジェク タアレイ15) 17) 18) が利用される. プロジェクタアレイを用い た裸眼立体表示システムの構成例を図6に示す。これは，リ 


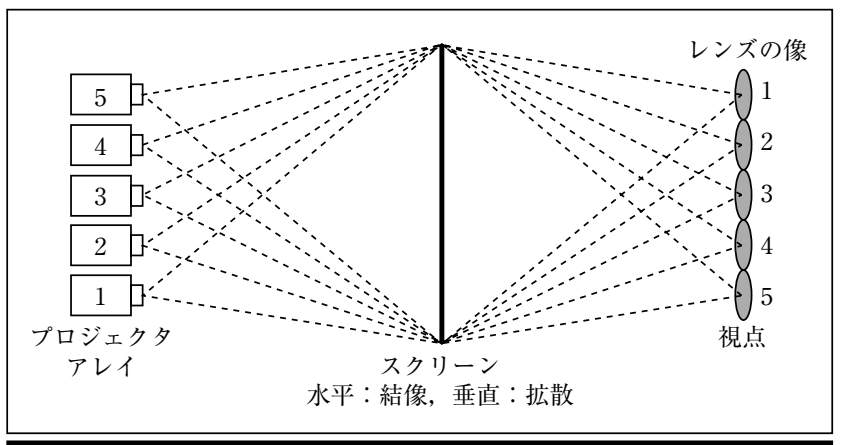

図6 プロジェクタアレイによる大画面立体表示（水平断面図）
アプロジェクション型の構成を示している．スクリーンはフ レネルレンズ等の大型レンズになっていて，プロジェクタの レンズの像を観察者側の空間に結像する。この結像位置に目 を置くと対応するプロジェクタの表示画像が見えるので，こ の結像位置が多眼表示の視点になる，また，通常はスクリー ンに垂直方向の拡散機能を持たせて, 垂直方向に視域を拡大 する. フロントプロジェクション型の構成は，スクリーンに 再帰性反射スクリーン等を用いることで実現できる.

画面の大型化は, 通常は観察者数増加の要求を伴う. そ のため, 大画面化は, 視点数増加や視域拡大が必要になる 点が難しい. フルHD解像度プロジェクタを63台用いた画 面サイズ200インチの大規模な表示システム25)の開発が報 告されている.

\section{6 利 用 形 態}

従来の2次元表示テレビは, 垂直表示面を正面から見る 利用形態を基本としている. 現状の立体ディスプレイもこ の形態 (図7 (a)) を基本とするが, 立体表示の場合は,さ まざまな利用形態が可能である.

図7 (b) に，円筒表示面を全周から観察する利用形態26)を 示す. 表示面の奥に立体表示することで, 円筒内部に物体 が存在するように表示できる.

図7 (c) に，水平表示面を全周から観察する利用形態27) 28) を示す．水平面上側に立体表示すれば，テーブルの上に物 が存在するように表示できる. 当然, 平面下側に立体表示 することもできる.

以上のように, 立体表示ではさまざまな利用形態が可能 であるため, 従来の 2 次元表示では実現できなかった新し い臨場感表現の実現が期待できる.

ただし, 垂直表示面に比べて, 円筒表示面や水平表示面 では, 観察距離が短くなる傾向があるため, 立体像のボケ が問題になる場合がある.

7 水平視差型と水平垂直視差型

立体ディスプレイは, 視差の与え方で, 水平視差型と水 平垂直視差型に分類できる．前者は水平方向にのみ視差を

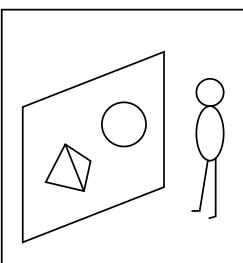

(a) 垂直表示面

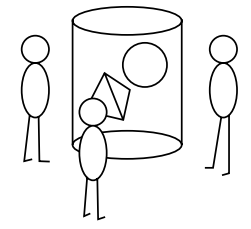

(b) 円筒表示面

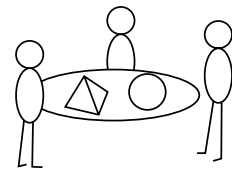

(c) 水平表示面
図7 立体ディスプレイの利用形態

もち, 後者は垂直方向にも視差をもつ.

ホログラフィは, 本来は水平垂直視差型として考案され た.しかし, 白色光再生 ${ }^{29)}$ や, 暗室以外での撮影・記録を 可能する ${ }^{30)}$ ために，水平視差型が開発された。電子ホログ ラフィでも, 水平視差型と水平垂直視差型があるが, 水平 視差型は表示情報量が少ないので，大画面化と広視域化に 適している。

光線再生型では, 水平視差型は1次元レンズアレイで, 水平垂直視差型は2次元レンズアレイで実現される. 水平 視差型の方が表示する画像情報が圧倒的に少ないので, 解 像度の高い立体像が得られる。そのため, 実用化されてい る立体ディスプレイは，ほとんどが水平視差型である.

人間の両眼は水平方向に並んでいるので，両眼視差情報 は水平視差が支配的で，通常の観察条件では垂直方向の人 体移動が小さいことから, 立体ディスプレイでは, 水平視 差型が古くから主流である. 現在, 商品化されているメガ ネあり立体テレビも，水平視差型である．垂直視差がない と寝ころんで見ることができないと言われることがある が，水平視差型を寝ころんで見ると 2 次元映像が見え，横 に動けは運動視差が生じる. 水平視差型は, 光線を重直方 向に拡散するため, 垂直方向の視域はかなり広い.

それでは, 垂直視差があることのメリットは何であろう か. 水平視差型では, 観察位置が奥行き方向に移動すると 立体像の縦横比が変化するが, 垂直視差型では, 正しい縦 横比が得られる. 水平視差型では, 垂直方向に光を拡散さ せるため立体像のボケが水平垂直で異なるが，水平垂直視 差型では等しい.

超臨場感という観点でみると, 解像度が高い点で水平視 差型が優れていて, 垂直方向の画像変化がある点で水平垂 直視差型が優れている.

\section{8 むす び}

超臨場感技術に必要な立体表示技術は，まだまだ研究開 発段階にある，超臨場感技術に必要な立体表示性能は, 超 臨場感とは何かを含めて, 今後, 明らかになるであろう. しかし, 超臨場感技術で用いられる立体表示技術の大きな 
特徵は, 単に表示装置の数值的な性能向上を狙うのではな く, 人間の存在を重要視し人間を含めた形での研究開発が 行われている点にある.このような新しい形の技術開発が, 今後の日本の国際競争力強化に繋がると思う.

(2011年2月10日受付)

\section{〔文 献〕}

1) D. Gabor: "A new microscopic principle", Nature 161, pp.777-778 (1948)

2) P.St. Hilaire, S.A. Benton and M. Lucente: "Synthetic aperture hologram: A novel approach to three-dimensional display", J. Opt. Soc. Am. 9, pp.1969-1977 (1992)

3) K. Maeno, N. Fukaya, O. Nishikawa, K. Sato and T. Honda: "Electroholographic display Using 15 mega pixels LCD", Proc. SPIE 2652, pp.15 (1996)

4) J. Hahn, H. Kim, Y. Lim, G. Park and B. Lee: "Wide viewing angle dynamic holographic stereogram with a curved array of spatial light modulators", Opt. Express 16, pp.12372-12386 (2009)

5) T. Senoh, T. Mishina, K. Yamamoto, R. Oi and T. Kurita: "ViewingZone-Angle-Expanded Color Electronic Holography System Using Ultra-High- Definition Liquid-Crystal Displays with Undesirable Light Elimination", J. of Display Tech., to be published

6) M. Stanley, et. al.: "100-megapixel computer- generated holographic images from Active Tiling: A dynamic and scalable electro-optic modulator system", SPIE 5005, pp.247 (2003)

7) R. Häussler, A. Schwerdtner, N. Leister: "Large holographic displays as an alternative to stereoscopic displays", SPIE 6803, pp.68030M-1-9 (2008)

8) Y. Takaki and Y. Hayashi: "Increased horizontal viewing zone angle of a hologram by resolution redistribution of a spatial light modulator", Appl. Opt. 47, pp.D6-D11 (2008)

9) Y. Takaki and N. Okada: "Hologram generation by horizontal scanning of a high-speed SLM", Appl. Opt. 48, pp.3255-3260 (2009)

10)S. Tay, et al.: "An updatable holographic three- dimensional display", Nature 451, pp.694-698 (2008)

11) 大越孝敬：“3次元画像工学”, 朝倉書店（1991）

12) M.G. Lippmann: "Epreuves reversibles donnant la sensation du relief", J. de Phys. 7, pp.821-825 (1908)

13)高木康博：“立体映像とフラットパネル型立体表示技術”, 光学, 35, pp.400-409 (2006)

14) T. Honda, et al.: "A display system for natural viewing of 3-D images", Three-dimensional television, video and display technologies, Springer-Verlag, Berlin Heidelberg, Germany, pp.461-487 (2002)

15) Y. Takaki: "High-Density Directional Display for Generating Natural Three-Dimensional Images", Proc. IEEE 94, pp.654-663 (2006)
16) Y. Takaki and H. Kikuta: "3D Images with Enhanced DOF Produced by 128-Directional Display", 13th International Display Workshops, pp.1909-1912 (2006)

17) H. Nakanuma, H. Kamei and Y. Takaki: "Natural 3D display with 128 directional images used for human-engineering evaluation", Proc. SPIE 5664, pp.28-35 (2005)

18) Kikuta and Y. Takaki: "Development of SVGA resolution 128-directional display", Proc. SPIE 6490, p.U1-8 (2007)

19) Y. Takaki: "Thin-type natural three-dimensional display with 72 directional images", Proc. SPIE 5664, pp.56-63 (2005)

20) Y. Takaki and T. Dairiki: "72-directional display having VGA resolution for high-appearance image generation", Proc. SPIE 6055 , 60551H1-8 (2006)

21)S.K. Kim, D.W. Kim, Y.M. Kwon and J.Y. Son: "Evaluation of the monocular depth cue in 3D displays", Opt. Express 16, 21415-21422 (2008)

22)金箱 翼，高木康博，"時間多重表示モジュールを用いた高密度指向 性立体ディスプレイ”，映情学誌，63，pp.1133-1138（2009）

23) Y. Takaki and N. Nago: "Multi-projection of lenticular displays to construct a 256-view super multi-view display", Opt. Express 18, pp.8824-8825 (2010)

24) Y. Takaki, Y. Tanaka and J. Nakamura: "Super multi-view display with a lower resolution flat-panel display", Opt. Express, to be published

25) 岩澤昭一郎, 矢野澄男, 河北真宏, 境雅久, 配野泰行, 佐藤正人, 安 藤広志：“プロジェクタアレイ方式裸眼立体ディスプレイの試作”, 映情技報，34，43，pp.29-32（2010）

26) T. Yendo et al.: "The Seelinder: Cylindrical 3D display viewable from 360 degrees", J. of Visual Communication and Image Representation 21, pp.586-594 (2010)

27)吉田俊介，矢野澄男，安藤広志：“周囲から観察可能な光線野再生型 テーブル様裸眼立体ディスプレイ”，3次元画像コンファレンス 2010 , pp.51-54 (2010)

28) H. Horimai, D. Horimai, T. Kousketsu, P.B. Lim and M. Inoue: "FullColor 3D Display System with 360 Degree Horizontal Viewing Angle", 3D映像, 24, 2, pp.7-10 (2010), http://www.holymine3d. $\mathrm{com} / \mathrm{prod} / \operatorname{prod} 03 . \mathrm{html}$

29)S.A. Benton: "Hologram reconstruction with extended incoherent sources", J. Opt. Soc. Am. 59, pp.1545-1546（1969）

30) J.T. McCrickerd and N. George: "Holographic stereogram from sequential component photographs", Appl. Phys. Lett. 12, pp.10-12 (1986)

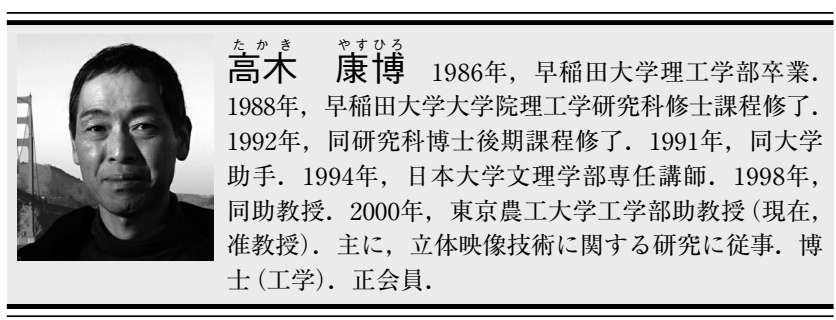

